\title{
THE IMPACT OF COVID-19 TOWARDS EMPLOYEE MOTIVATION AND DEMOTIVATION INFLUENCE EMPLOYEE PERFORMANCE: A STUDY OF SAYURMOMS \\ Oleh :
}

Clara Anisah

School of Business and Management, Bandung Institute of Technology

Email : clara anisah@sbm-itb.ac.id

\author{
Article Info \\ Article History: \\ Received 13 Sept - 2021 \\ Accepted 25 Sept - 2021 \\ Available Online 25 Sept - \\ 2021
}

\begin{abstract}
Indonesia as a developing country, development is happening very rapidly and competing with each other in prioritizing quality. To maximize quality, good human resource management is needed. In their growing stage, there is a small business that is still developing called 'Sayurmoms'. From the 10 months Objective Key Result (OKR) From July 2020 to May 2021. Sayurmoms only reach average at level $31,5 \%$ during COVID19. The research objective in this research is to understand the employee motivation and demotivation during COVID-19 that influenced the employee performance on Sayurmoms. The research methodology approach will be qualitative research, which is a way for examining and comprehending an individual's or an organization's impact on a social or human issue. In this case the individuals are the employees in Sayurmoms and the human problem is the motivation and demotivation during COVID-19. This study will employ qualitative phenomenology analysis in order for the researcher to gain a better understanding of the phenomenon from Sayurmoms' employee's point of view regarding the COVID-19 phenomenon that causes the employee to work from home and its impact on their motivation and demotivation with using in-depth interview for the data collection. This research plays a role in giving the solution for Sayurmoms in mitigating the employee demotivation and increasing employee motivation.
\end{abstract}

COVID-19 Pandemic;

Employee Motivation;

Employee Demotivation;

Employee Performance

\section{BACKGROUND}

Indonesia is a developing country that has great potential to compete with other countries. Especially for its startups. Since 2015, Indonesia's online economy has grown at a rate of 49 percent per year on average. This rate of growth has surpassed all forecasts, establishing Indonesia as Southeast Asia's largest and fastest-growing Internet economy, on track to surpass $\$ 130$ billion by 2025 (World Bank,
2020). As a developing country, of course, development is happening very rapidly and competing with each other in prioritizing quality. To maximize quality, good human resource management is needed. With the proper management of human resources it will also have a good impact on work results and indirectly will have a good impact on the company. In other words, it can be concluded that human resources are the main key to be 
able to compete in the free market era. To get good human resources, there needs to be a trigger so that someone wants to do something better, resulting in good performance. One of the trigger factors is good motivation. But besides motivation, of course there is demotivation, which is a trigger for someone to hinder their performance (Maslow, 1954).

Current conditions show that all companies are unstable because they experience the same problems in ensuring the continuity of the work rights of each employee amid the Covid-19 pandemic. Under these conditions, many companies are forced to reduce the number of employees, which means that the effectiveness and efficiency of the company's performance has decreased drastically. The COVID-19 pandemic has had a significant impact on Indonesia's economy. Last year, Indonesia's economy slowed, and the country's economy is anticipated to continue under strain in 2021, as the pandemic shows no indications of abating. Tourism, transportation, logistics, and the hotel industry are among the industries that have been hurt the worst (United Nations Development Programme, 2020). The impact of the Covid-19 pandemic is very troubling for all parties, changes in work methods and patterns that must be in accordance with health protocols so that it has an impact on the workload of more employees, due to a significant reduction and making the workload assigned larger than before. Workload is a set or a number of activities that must be completed by an organizational unit or office holder within a certain period of time (Dhania, 2010). Excessive workload will have an adverse impact, namely causing physical and mental fatigue, as well as emotional reactions.

Remote work is becoming a more popular form of working around the world, and the COVID-19 epidemic has had an impact on this trend. Remote work is a recent phenomena, and because it has grown rapidly around the world, it is critical to analyze how the change and new way of working operate in practice, how remote working affects employee motivation and demotivation, and what the benefits and drawbacks of remote work are.

Employee motivation influences what they do, how they do it, and how hard they work
(Graves \& Sarkis, 2018). Extrinsic and intrinsic motivation are two types of motivation. Salary, working conditions, fringe benefits, security and promotion, service contracts, and employment work environment and conditions are examples of extrinsic motivation. While intrinsic motivation persists, the other side of the coin is appreciation, which can be referred to as psychological motivation. Examples include opportunities to employ abilities, tastes, challenges, and achievements, earning awards, positive acknowledgment, and being treated with compassion (Muogbo, 2013). Motivation is one of the key factors to increase the effectiveness of a company. Motivation itself is influenced by many factors, including the social, cultural, and individual environment of each person. This is what causes the absence of a standard that can be used to measure and compare the level of motivation between one company and another (Herzberg, 1968).

Motivation at work is defined as motivation that is linked to high levels of employee engagement and job satisfaction. Many people have accepted this understanding of motivation as sound and convincing, despite the fact that it is a very different view of motivation (and, by extension, demotivation) than that held by more traditional psychologists who are more interested in a broader understanding of human behavior in general (Hezberg, 1969).

Demotivation is linked to low levels of employee engagement and job dissatisfaction. defined as a "counterproductive process" characterized by six phases that contribute to a "loss of motivation," including perplexity, anger, latent hope, disillusionment, uncooperativeness, and departure, and is "a good indicator of dissatisfaction" in workplaces (Mayer, 1978).

In their growing stage, there is a startup that is still developing called 'Sayurmoms'. From the 10 months Objective Key Result (OKR) From July 2020 to May 2021. Sayurmoms only reach average at level 31,5\% during COVID19. Based on the preliminary research which is the discussion among the Sayurmoms' team members. It proves that the root causes of failing to achieve the Objective Key Result (OKR) because of the demotivation that 
happened in our company, and the job description is not clear that, we almost do every single task that exists by ourselves, regardless of our division. The job description is also possibly affecting the motivation.

Based on (Rick Klau, 2013), there are two types of OKR, which are Moonshots and the second type of OKR which is Roofshots. In the Moonshots, Just beyond the horizon of what appears to be possible, and achieving around $60-70 \%$ means success. Moonshots are a foundational building block of OKR. Goals that are challenging but attainable. The term "success" refers to attaining 100 percent of one's goals.

\section{LITERATURE REVIEW AND HYPOTHESES DEVELOPMENT Emerging Changes to Remote Working During COVID-19}

Working from home (WFH) has had an impact ondemotivation.

\section{employee performance as a result of the COVID-Employee Performance}

19 pandemic, which has changed the methods and cultures of work in many organizations. Working from home (WFH) is described as working from a location other than the workplace (Mustajab, et al. 2020) . As a result, employers and managers must communicate and collaborate using current technology. Remote working necessitates the provision of computers, mobile phones, access to a work email account, and other relevant platforms such as videoconferencing technology by the business.

\section{Employee Motivation}

Motivation, according to Behnaz (2013), is a psychological process that can drive and motivate an individual, whether it's to reach the top of the sales objective or to be a good team member. Motivation can also be a strength of an individual's behavior that motivates him or her to achieve goals and so increase productivity (U.S, 2013). When an employee's wants and expectations are addressed by the organization/management, it inspires people to work toward the organization's common goals and objectives, whether at a group or individual level (Haque, et al. 2014).

\section{Employee Demotivation}

Mayer (1978) defined demotivation as a "counterproductive process" characterized by six phases that contribute to a "loss of motivation," including confusion, anger, subconscious hope, disillusionment, uncooperativeness, and departure, and which "is a good indicator of unrest" in the workplace.

Spitzer (1995) gave what appears to be a more applicable interpretation of the term, defining the "seven deadly demotivators," which he defines as "negative motivational elements" that "frustrate employees and drive them to utilize less productive energy in their occupations." This concept seems to be more in line with the original definition of demotivation, at least in terms of how these things are regarded as diminishing overall activity. This is mostly centered on the workplace, but it may potentially apply to their entire life experience. As a result, such variables could contribute to a localized or overall decrease in activity, however it appears improbable. As a result, such variables could contribute to a localized or general decrease in activity, although that appears doubtful that they would often result in an individual's overall Employee performance includes the results of their actions which are dependent on their actions and capabilities. Employee performance in organizational contexts is the sum of all employees' talents, efforts, and abilities that led to the organization's increased productivity and attainment of its goals. Improved organizational performance is a sign that things are getting better. Enhanced organizational performance reflects efforts toward goal achievement, while improved employee performance necessitates even greater effort (Ellinger, et al. 2003).

\section{RESEARCH METHODS}

The research approach will be qualitative research, which is a way for examining and comprehending an individual's or an organization's impact on a social or human issue (Creswell, 2014). In this case the individuals are the employees in Sayurmoms and the human problem is the motivation and demotivation during COVID-19. However, because this method is better suited to small samples, using the data to characterize a larger population is risky. (Bell, 2005). Preliminary research is research on a topic that helps the researcher understand what sources are accessible and what is being said about it. By 
widening or narrowing a topic, this form of study helps to cement it.

This study can also aid in the selection of Search Terms. At the very first beginning of the research, the researcher do the preliminary research with her own observation in the Sayurmoms company. Furthermore, to make sure that the problem existing is non-biased by the researcher observation itself, the researcher did the conversation between the Sayurmoms' members regarding their progress, milestones and their personal improvement and development.

The researcher is using to complete this study is a primary data that will be collected qualitatively and will be used to provide deeper understanding about the working condition and behavior of the employee motivation and demotivation during COVID-19 that influences the employee performance in Sayurmoms Company.

The data that was collected by in-depth interview result was analyzed with qualitative coding.

\section{Data Validity and Reliability}

The validity and reliability of qualitative data are the most important considerations. When the data collection passes the validity and reliability tests, an instrument is deemed a good measure (Dikko, 2016). Validity refers to whether or not the research can be trusted, as well as whether or not it is evaluating what it claims to be evaluating (Zohrabi, 2013). In this sense, the quality of the interview instrument is critical because the information acquired from the instrument determines the research's conclusion.

Meanwhile, in terms of the instrument's reliability, the data is subjective and in narrative form, which may make the analysis part problematic. However, a study is regarded credible when the interview data is consistent and when it measures the ideas that it is designed to test without bias (Sekaran \& Bougie, 2003). As a result, in this investigation, both validity and reliability are crucial.

According to Patton (1990), the validity and reliability of qualitative data are highly dependent on the researcher, who expects to be the central character in the interview session.
The researcher's role in conducting the interview session is critical in ensuring that respondents comprehend the questions presented while also obtaining the data needed to answer the research questions. A researcher is supposed to construct an overview of the technique that can be simply followed, with concepts that can be measured and procedures that can sufficiently accomplish the work when performing a study (Dikko, 2016).

In any research, a pilot test is carried out to confirm that the validity is reached. It is defined as a version of a research instrument that has been pre-tested prior to the actual study being conducted (Majid et.al, 2001). A number of authors have emphasized the importance of conducting the pilot test, stating that it aids in the early detection of any potential flaws in the instrument by identifying potential problems and areas that may require instrument adjustments (Dikko, 2016; Teijlingen \& Hundley, 2001; Watson, Atkinson, \& Rose, 2007), as well as adding value and credibility to the research.

\section{RESULTS AND DISCUSSION Transcendental-Phenomenological Reduction (Epoche)}

Epoche stage requires us to put aside our daily understanding, knowledge, and judgment of a phenomenon, so that the phenomenon we get is a new perspective, free from ego because the phenomena we get are elements of purity from an object. Husserl explained that this method includes bracketing which requires us to suspend our natural attitude from all things related to life that are taken for granted in order to achieve the goal of obtaining a pure understanding of the phenomenon under investigation. The correct understanding of a phenomenon according to the transcendental phenomenology can be judged only if personal biases, interests, and historical values can be purified based on the time of investigation (Ardianto et al., 2007).

\section{Horizonalization}

Horizonalization is the process of assigning equal weight to each statement or horizon from each interview as it relates to the topic or research questions (Moustakas, 1994). The researcher reviewed the interviews and the 
photo-elicitation session, as well as the materials submitted by the research participant, during this phase of the study. Because they stand out amongst all of the other statements, the researchers viewed each statement as having equal importance and listed every phrase relevant to the event (Moustakas, 1994). The researcher completed the horizonalization process by compiling all of the interview transcripts into a master list and then highlighting the information that was pertinent to the experience.

\section{Structural Analysis}

\section{How Employee Motivation Factors Influence Employee Performance}

The employee motivating factors by (Herzberg, 1959) consist of achievement, recognition, responsibility, work itself, advancement, and personal growth. Motivating factors called satisfiers as well The intrinsic value and happiness derived from the job itself are the key motivating factors, not the setting. As a result, in order to inspire an individual, a job must be hard, offer opportunities for growth, and be of interest to the employee. Motivators (also known as satisfiers') are those aspects of a job that are directly related to job satisfaction.

The first factor is achievement, they felt that there is the relationship between employee motivation and employee performance. But it is very unfortunate that the achievement in Sayurmoms does not exists. This refers when they are proud to work for this company because it honors their accomplishments, and they are content with their employment since it provides them a sense of success and that they have made a meaningful contribution to the organization. For the CMO and CBDO, they don't feel the meaningful contribution to the organization and their accomplishments are not honored. While the CEO felt that she is proud to work for this company, content with her employment, sense of success and meaningful contribution.

The second factor is Recognition. All of the Sayurmoms employees felt that there is the relationship in recognition affecting the motivation that influence employee performance. This refers to when they feel appreciate when accomplish or complete a task and am thanked for a job that well done, as well as receiving proper recognition for that as well. But, at the same time this thing is not exist in Sayurmoms. They don't feel appreciate when accomplish or complete a task and not thanked for the job that well done.

Third factor is responsibility. Responsibility have played a huge role in motivation, that is what the Sayurmoms employee felt about the relationship between the responsibility and motivation and have the influence towards employee performance. This refers to when the employees have given the trust to carry responsibility and the freedom of decision making. But, the chane to give responsibility and the freedom of making the decision making is only on the CEO's hand while the other employees do not have the chance. Towards the personal motivation, employees felt that much appreciated and given the trust from the company with giving the responsibility.

Fourth factor is work itself, all of the sayurmoms employees have agreed that they feel work itself is having the impact towards employee motivation that influence the employee performance. Work itself refers to when the work is interesting, and they have a wide variety of responsibilities to complete; they have the job that suits their division; they are empowered to execute their jobs, and their work is challenging and interesting. But, unfortunately this thing do not happen in Sayurmoms. They don't get the job that is interesting and have a wide variety, they also got the job that does not suits their division.

Fifth factor is advancement, advancement does not exist in the Sayurmoms because they have reached the higher positions, because they are all the Sayurmoms' founders.

The last motivating factor is the possibility of growth refers to when they are proud to work for the company because they believe they have developed as individuals, and their position allows them to continue to grow and develop as individuals, as well as improve their experience, skills, and performance. This motivating factor do not exist as well in Sayurmoms especially for the CMO and CBDO because the employees keep doing the same assignment again and again. This does not 
make them grow as the employee. The Sayurmoms' employees feel that there is the relationship between possibility of growth and motivation influence the employee performance. While the CEO felt she has grown really a lot because she is supposed to learn a lot of things as a CEO.

After analyzing the motivating factors. The researcher can see that none of this motivating factors exist in the company. But, there are two factors that exists based on the Chief Executive Officer (CEO) point of view, which is the achievement and the possibility of growth which produced the achievement of the revenue section of the OKR by the CEO.

\section{How Employee Demotivation Factors Influence Employee Performance}

The demotivation factors are considered as the hygiene factors at Herzberg Theory. Due to a lack of motivators, people tend to focus too much on hygiene factors, which are the unpleasant aspects that can be seen and hence are the source of complaint and concern. Because of the urge to avoid unpleasantness, hygiene considerations (also known as maintenance factors) lead to job unhappiness. The crucial thing to understand is that while paying attention to these hygiene elements reduces discontent, it does not always result in positive motivation. Dissatisfiers are a term used to describe hygiene factors. They are concerned with aspects of the job that are related to it but are not directly related to it.

The first and second demotivation factors in this theory are working conditions and coworker relations. This refers to their coworkers are easy to get along with, they are helpful and friendly, and their coworkers are essential to them. The working environment and features of an employee's terms and conditions of employment are referred to as working conditions. This includes topics like work organization and activities, as well as training, skills, and employability, health, safety, and well-being, and working time and work-life balance. The researcher found out that this has impacted a lot to the demotivation because of losing the working conditions and coworker relations due to the COVID-19 forcing them to have virtual interaction has caused the demotivation. All of the Sayurmoms employees have agreed that there is the relationship between working conditions towards performance as well as coworker relations to the employee performance.

The third demotivation factor is Policies and Rules. This refers to: the administration's attitude at the company is very accommodating; they are glad to work for this company because its policies are favorable to its employees, and they fully comprehend the company's objective. The employees are all feel that this has the relationship between policies and rules towards employee motivation. Because of the nonexistence of policies and rules, Sayurmoms employees sometimes had no idea about what to do. There is no clear polices and rules has caused the demotivation in Sayurmoms.

The fourth factor is the supervisor quality. This refers to the ability of the employees in improving their performance because of their supervised work. Every employees have felt the relationship regarding supervisor quality that impacted the employee demotivation influence employee performance. Supervisor quality is really affecting the employee assignment's quality. Unfortunately, this thing is not existed in Sayurmoms. Due to this, it feels like they do not really pay attention to the work quality because no one supervise them. While the CEO as the one who supposes to supervise and control them, have mentioned that the supervisor quality needs to be implemented as soon as possible.

Fifth demotivation factor is base wage and salary. This refers to because of their base wage and salary, they are motivated to work harder and getting the fair salary equal to the contribution that they give. Sayurmoms employees have felt relationship between employee demotivation and performance regarding base wage and salary. Which is very unfortunate, Sayurmoms don't paid their employee. This issue has made the Sayurmoms employee felt they don't have the responsibility. Because, they don't get the feedback equal to their contribution.

Sixth demotivation factor is the Status. This refers to They believe it is safe to work at the workplace, that their job is secure, and that their workplace is in an area where they feel at ease. All of the Sayurmoms employees' have 
felt that there is the relationship between status to the employee demotivation influence employee performance. Even though has a lot of growth and sales, two employees in Sayurmoms considered this is not the job security because there are no formal bonding worker relations. While the CEO felt this is the job security because she believes it is safe to work at the workplace and having the job security.

After analyzing the demotivation factors. The researcher can see that none of these motivating factors exist in the company. But, there is one factor that exists based on the Chief Executive Officer (CEO) point of view, which is the Status which produced the achievement of the revenue section of the OKR by the CEO.

\section{Discussion - Eidetic Reduction}

The demotivation factors are considered as the hygiene factors at Herzberg It has proven that the employee motivation and demotivation has the major impact towards the employee performance. Especially during COVID-19 pandemic, when the employees are not able to meet directly face to face that forces them to interact through online communication. There are several motivation and demotivation factors that really depend on the face to face interaction and will decrease its value when it is held through online media.

The existence of COVID-19 really affects the motivation and demotivation factors. Because, the demotivation factors are not coming from the job itself, but it comes from surrounding the job. The psychological and physical environments in which people labor are demotivating elements. The structure of the business, as well as internal aspects such as physical working environment, company policies, job security, supervision quality, salary, and employee relationships with others, are all essential hygiene factors.

The demotivation factor such as working conditions that are constantly changing before and during the COVID-19 pandemic. They now regard the fear of catching the virus as a cause for even more concern, making working conditions even more stressful. The other demotivation factor that is affected by COVID19 is co-worker relations. Employees' capacity to do their tasks is determined by their interpersonal relationships; people demand peer trustworthiness before investing in new partnerships. To establish trust, it is critical to offer assistance and express feelings of care and concern for one another. People must trust that they may speak freely with their peers and that others will listen and reply in a beneficial and caring manner. Both parties must have an emotional involvement in the working relationship; for example, if one team member is no longer able to work, the remaining team members will feel lost.

The COVID-19 pandemic presents leaders with a major and imminent adaptation challenge. To strengthen the organization's ability to endure amid a crisis, leaders must take responsibility for their organizations by developing trust, collaborating, and sharing leadership. Furthermore, authentic leadership necessitates empathy, compassion, and flexibility in order to manage employees who are stressed by uncertain situations, and leaders must possess both emotional intelligence and emotional stability in order to lead their organizations, because organizational employees face real challenges on a daily basis. This research is in line with (Haqiel et al, 2014) literature, which is motivation can be a strength of an individual's behavior that motivates him or her to achieve goals and so increase productivity. When an employee's wants and expectations are addressed by the organization/management, it inspires people to work toward the organization's common goals and objectives, whether at a group or individual level. As well as to (Spitzer, 1995), "negative motivational elements" that "frustrate employees and drive them to utilize less productive energy in their occupations." This concept seems to be more in line with the original definition of demotivation, at least in terms of how these things are regarded as diminishing overall activity. This is mostly centered on the workplace, but it may potentially apply to their entire life experience. As a result, such variables could contribute to a localized or overall decrease in activity, however it appears improbable. As a result, such variables could contribute to a localized or general decrease in activity, although that appears doubtful that they would often result in 
an individual's overall demotivation. This research is in line as well to the (Ellinger et al, 2003) Employee performance includes the results of their actions, which are dependent on their experience and capabilities. Employee performance in organizational contexts is the sum of all employees' talents, efforts, and abilities that led to the organization's increased productivity and attainment of its goals. Improved organizational performance is a sign that things are getting better. Enhanced organizational performance reflects efforts toward goal achievement, while improved employee performance necessitates even greater effort.

This study is also in keeping with the fact that financial motivation has become the most important worry in today's organizations, and, according to Masllow's basic demands, nonfinancial motivation only comes the equation when financial motivation has failed.

With the framework that has been built, it proves that the COVID-19 has the impact towards employee motivation and employee demotivation that affects employee performance.

\section{KESIMPULAN}

Due to the nonexistence of the whole motivation factors for $\mathrm{CMO}$ and $\mathrm{CBDO}$ such as no achievement, no recognition, does not given the trust for work itself, no responsibility, no advancement and no possibility of growth while for the CEO only two factors exist which are the achievement and the possibility of growth. Therefore, the motivation in Sayurmoms is categorized as low motivation.

Due to the existence of the whole demotivation factors for CMO and CBDO such as bad working conditions, less coworker relations, no policies and rules, no base wage $\&$ salary, no supervisor quality and no status while for the CEO only not experience on factor which is the status. Therefore, the motivation in Sayurmoms is categorized as high demotivation.

With low motivation and high demotivation, this is the worst possible scenario for any company or team. Employees are unpaid and the labor is uninspiring under this situation. If the situation does not improve, employees will begin to leave the company unless their issues are addressed.

\section{REFERENSI}

Akanbi, Paul Ayobami. (2011). Influence of Extrinsic and Intrinsic Motivation on Employees' Performance. Journal of Management and Corporate Governance. http://www.ilo.org/public/english/iira/docume nts/congresses/regional/lagos2011/3rdparallel/ session3b/motivationworker.pdf

Ardianto, Elvinaro, dkk. 2007. Komunikasi Massa. Bandung: Simbiosa Rekatama Media.

Armstrong, M. (2012). Armstrong's Handbook of Human Resource Management Practice. London: Kogan Page.

Bajpai, N., Business research methods2011: Pearson Education India

Barber, A.E. \& Bretz, R.D. Jr. (2000). Compensation, attraction and retention. In S.L. Rynes \& B. Gerhart (Eds.), Compensation in Organizations, 32-61. San Francisco: JosseyBass.

Beattie, R. S., Kim, S., Hagen, M. S., Egan, T. M., Ellinger, A. D., \& Hamlin, R. G. (2014). Managerial coaching. A review of the empirical literature and development of a model to guide future practice. Advances in Developing Human Resources, 16(2), 184-201.

Bell, J. (2005). Doing Your Research Project: A Guide for First-Time Researchers in Education, Health and Social Science (4th ed.). Berkshire: Open University Press.

between perceived job autonomy and work performance', European Journal of Work and Organizational Psychology, 20:

Camilleri, M.A. (Ed.) Strategic Corporate Communication in the Digital Age, Emerald Publishing Limited, Bingley, pp. 251-252. https://doi.org/10.1108/978-1-80071-264520211017

Creswell, J. W. (2007). Qualitative inquiry and research design: Choosing among five approaches (2nd ed.). Sage Publications, Inc.

Creswell, John W. A Concise Introduction to Mixed Methods Research. Thousand Oaks, California: SAGE, 2015.

Creswell, John W. Research Design: Qualitative, Quantitative, and Mixed Methods Approaches. Thousand Oaks, Calif: Sage Publications, 2003. Print.

Dysvik, A., \& Kuvaas, B. (2011). Intrinsic motivation as a moderator on the relationship 
between perceived job autonomy and work performance. European Journal of Work and Organizational Psychology, 20(3), 367-387. https://doi.org/10.1080/13594321003590630

Faustino Cardoso Gomes. 1995. Human Resourses Management. Andi Offset Pubsher. Yogyakarta.

Foote, N. N., Mayer, R. N. (1974) "Technology, affluence, and consumers: searching for useful perspectives," Vol. 5 in Nicosia, F. M., Technological Change, Product Proliferation, and Consumer Decision Processes. Washington, DC: National Science Foundation

Freedman, D., Pisani, R., \& Purves, R. (1998). Statistics. New York: W.W. Norton.

Frey, B. and Osterloh, M. (2002) Successful Management by Motivation: Balancing Intrinsic and Extrinsic Motivation. Springer, Berlin. http://dx.doi.org/10.1007/978-3-662-10132-2

Gibson, J.L., Ivancevich, J.M. and Donelly, Jr., J.H. 1985. Organizations. 5 th Edition. Business Publication, Inc.

Gitongu, M. K., Kingi, W. and Uzel, J. M. M. 2016, 'Determinants of Employees' Performance of State Parastatals in Kenya: Kenya Ports Authority", International Journal of Humanities and Social Science, vol. 6, no. 10, pp. 197-204.

Grant, A. M. (2008). The significance of task significance: Job performance effects, relational mechanisms, and boundary conditions. Journal of Applied Psychology, 93(1), 108-124. https://doi.org/10.1037/00219010.93.1.108

Graves, LM, Sarkis, J., \& Zhu, Q. (2013). How Transformational Leadership and Employee Motivation Combine to Predict Employee Proenvironmental Behaviors in China. Journal of Environmental Psychology. Vol 35, 81-91.

Güngör, P. (2011). The Relationship between Reward Management System and Employee Performance with the Mediating Role of Motivation: A Quantitative Study on Global Banks. Procedia - Social and Behavioral Sciences, 24(The Proceedings of 7th International Strategic Management Conference), 1510-1520.
Guo, F., Cerullo, I., Chen, X., Rosbash, M. (2014). PDF neuron firing phase-shifts key circadian activity neurons in Drosophila.

Haque, M.F., Islam, and Md,.Haque, M.A. (2014). Motivational Theories - A Critical Analysis. ASA University Review. 8 (1). p. 6164

Herzberg, F. (1968) One More Time: How Do You Motivate Employees? Harvard Business Review, 46, 53-62.

Herzberg, F., Mausner, B., \& Snyderman, B. (1959). The motivation to work (2nd ed.). John Wiley.

Jewell, L. N. \& M. Siegall. (1990). "Contemporary industrial/ organizational psychology." West Publishing Company.

Kotler, P. and Keller, K.L. (2005) Marketing Management. 12th Edition, Prentice-Hall of India Private Limited, New Delhi.

Kuswarno, Engkus. 2009. Fenomenologi. Bandung: Widya Padjadjaran.

McGregor, D. (1960) The Human Side of Enterprise. McGraw-Hill Book Co., New York.

Mitchell, Robert \& Schuster, Lisa \& Jin, Hyun Seung (2020). "Gamification and the impact of extrinsic motivation on needs satisfaction: Making work fun?," Journal of Business Research, Elsevier, vol. 106(C), pages 323-330.

Moustakas, C. (1994). Phenomenological Research Methods. Thousand Oaks, CA: Sage. Muogbo, U. S. (2013). The Impact of Employee Motivation on Organisational Performance (A Study of Some Selected Firms in Anambra State Nigeria). The International Journal of Engineering and Science, 2(7), 7080.

Paul, J. P., Robertson, K. B., \& Herzberg, F. (1969). Job enrichment pays off. Harvard Business Review, 47(2), 61-78.

Prasad, C. S. ; Gowda, N. K. S., 2005. Dietary level and plasma concentration of micronutrients in crossbred dairy cows fed finger millet and rice straw as dryroughage source. Indian J. Dairy Sci., 58 (2): 109-112

Ritson, N. (2008). Strategic Management. Neil Ritson and Ventus Publishing ApS. Retrieved from http://lib.mdp.ac.id/ebook/Karya Umum/Karya Umum-Neil Ritson.pdf 
Rollinson, D., \& Broadfield, A. (2002). Organisational Behaviour and Analysis: An Integrated Approach (2nd ed.). Gasport: Ashford Colour Press.

Ryan, R. M., \& Deci, E. L. (2000). Selfdetermination theory and the facilitation of intrinsic motivation, social development, and well-being. American Psychologist, 55(1), 6878. https://doi.org/10.1037/0003-066X.55.1.68

Sara Ghaffari, Dr. Ishak Mad Shah, Dr. John Burgoyne, Dr. Mohammad Nazri, Jalal Rezk Salleh., The Influence of Motivation on Job Performance: A Case Study at Universiti Teknologi Malaysia. Aust. J. Basic \& Appl. Sci., 11(4): 92-99, 2017

Singh, Jagdip , Goolsby, Jerry R. , and Rhoads, Gary K. (1994), "Behavioral and Psychological Consequences of Boundary Spanning: Burnout for Customer Service Representatives," Journal of Marketing Research, 31 (November), 558-69.

Singh, Jagdip , Goolsby, Jerry R. , and Rhoads, Gary K. , and Rhoads, Gary K. (1991), "Boundary Role Ambiguity in MarketingOriented Positions: A Multidimensional Multifaceted Operationalization," Journal of Marketing Research, 28 (August), 328-38.

Singh, Jagdip , Goolsby, Jerry R. , and Rhoads, Gary K. , and Rhoads, Gary K. , Verbeke, Willem and Rhoads, Gary (1996), "Do Organizational Practices Matter in Role Stress Processes? A Study of Direct and Moderating Effects for Marketing-Oriented Boundary Spanners," Journal of Marketing, 60 (July), 69-86.

Sulaiman, J., Azman, A. \& Saboori, B. (2013). The Potentialof Renewable Energy: Using The Environmental Kuznets Curve Model. American Journal of Environmental Sciences, $\quad 9(2)$, 103-112. https://doi.org/10.3844/ajessp.2013.103.112

Vansteenkiste, M., \& Ryan, R. M. (2013). On psychological growth and vulnerability: Basic psychological need satisfaction and need frustration as a unifying principle. Journal of Psychotherapy Integration, 23(3), 263-280. https://doi.org/10.1037/a0032359

Venkatraman, N. and Ramanujam, V. (1986) Measurement of Business Performance in Strategy Research: A Comparison of Approaches. Academy of Management 